\title{
The relationship between novice and experienced EFL teachers' critical thinking ability and their successful teaching
}

Beizaee, Anahita $\bowtie$

Islamic Azad University Science \& Research Branch, Neyshabur, Iran (Beizaee75@gmail.com) Akbari, Omid

Imam Reza International University, Mashhad, Iran (omidakbari@imamreza.ac.ir)

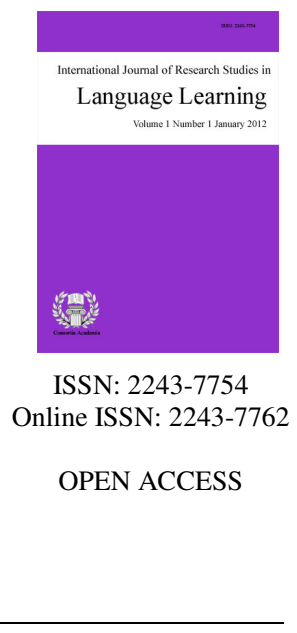

Received: 8 December 2015
Available Online: 26 February 2016

Revised: 14 February 2016 DOI: $10.5861 /$ ijrsll.2016.1392

Accepted: 16 February 2016

\section{Abstract}

The root of critical thinking is so ancient and refers back to the 2,500 years ago. It was the importance of asking deep questions that needs thinking before we accept ideas. The idea has motivated the educators to examine the role of it in teaching profession. The purpose of this study was to investigate the relationship between the critical thinking ability of EFL teachers and their successful teaching. One hundred intermediate students learning English were subjects of this study. They were common among the teachers. Also, fifty males and females teachers of these students from Jahad-e- daneshgahi, Alefba, and Marefat language school were selected. As the first step, teachers were given Watson-Glaser critical thinking questionnaire to fill on their free time. It was comprised of 80 items. Afterward, their students were given Successful Iranian EFL Teachers Questionnaire which is designed by Moafian and Pishghadam (2009). To fulfill the objectives, some statistical techniques such as Pearson correlation coefficient between the variables, ANOVA and regression were conducted. The result of the analyses related to the scores obtained from these two tests showed that there was no significant relationship between critical thinking ability of teachers and their successful teaching. But it revealed that as the age and experience of teachers increase their thinking ability increases too. The aim of the researcher was to focus more on critical thinking skill and application of that in the field of the teaching profession to help teachers to be more successful.

Keywords: critical thinking; successful teaching; novice teacher; experienced teacher 


\section{The relationship between novice and experienced EFL teachers' critical thinking ability and their successful teaching}

\section{Introduction}

Studies on teachers' belief and thinking yields different meaning such as professional identities, roles, responsibilities of the teachers, their conception about goal of education, beliefs about students' learning, and teachers' understanding of teaching practice (Beijaard, Meijer, \& Verloop, 2004; Brookhart \& Freeman, 1992; Kagan, Sandretto, \& Heath, 2002; Pajares, 1992; Vanden Berg, 2002). Ornstein (1995) has mentioned that the image of an expert teacher is pivotal in successful teaching. So, expert teachers teach more effective. Teachers' conceptions and successful teaching has attracted attention for many years; but there are still many questions in this field. There is need for further studies on teachers meaning (Van den Berg, 2002). Kane et al. (2002) performed many studies in the field and underlined the need for more research on teaching practice and teacher education.

Teachers' thinking are of considerable importance for understanding and improving educational process. They serve as guides for language teachers in adopting some teaching strategies for everyday teaching challenges. They have influence on their general well-being, motivating learners, shaping learning environment, and ability and language achievement. In this regard, Freeman (2002) suggested that, exploring teacher thinking may arise many different questions related to the conceptual framework and the appropriate research methodologies in order to address the basis for language teachers' knowledge. According to Demirel (1999), critical thinking is basically the ability and tendency of obtaining, evaluating, and using information in an effective way.

In the recent years attention has been paid to critical thinking. CT guarantees human progress. Caroll (2004) believes that it is "often the critical thinkers who shake up existing beliefs and practices. On a more prosaic level everyone should have the tools to make reasonable decisions about matter that affect them" (p. 12). Critical thinking has been an essential issue in education. One of primary goals of education is to enhance ability of thinking critically. Everyone knows the value and the need for critical thinking. It is not enough to have intelligence and great knowledge for thinking critically; instead we should know how to use our intelligence and knowledge to reach goals and objectives. Critical thinker can better make decision and solve the problems compared to others. Teachers in general and English language teachers in particular have an essential role in bringing better learning and achievement in their learners. As Markley (2004) pointed out effective learning in learners is influenced by what teachers do in their classes.

The methods teachers use are affected by their perception of effective teaching. Many researches have been done in relation to teachers' development during the past 60 years and they have tried to find criteria to investigate successful teaching. Researchers have established some attributes which are enthusiasm (Murray, 1991). Successful teaching is a highly debatable topic. For instance, the growth in psychology and cognitive sciences has conducted the researchers to consider cognitive, affective and personality characteristics of teachers and the role of them in teaching success. One viable domain to examine the concept of successful teaching in foreign language teaching is teachers' critical thinking.

In a rapidly-changing world where almost nothing can be taken for granted, 'critical thinking' seems to be a solution. Regarding critical thinking as the ability to discipline and control thinking to process information more easily, effectively and efficiently (Paul, 1990; cited in Longman, Atkinson, \& Breeden, 1997), it is important for learners to perform well not only in educational systems, but also in future workplaces, and social areas. Critical thinking researches have focused on ways of developing this skill in learners (e.g., Dantas-Whitney, 2002; Faravani, 2006), and failed to examine its application to teachers' success and the effectiveness of teacher 
education programs. It is obvious that in order to train learners for ways of thinking, teachers themselves must be able to think in those terms. The questions of how teachable critical thinking is and to what extent current EFL/ESL teacher education programs implicitly or explicitly draw on the construct are yet to be answered. However, before addressing such questions, the number-one issue to be investigated is the extent to which $\mathrm{EFL}$ teachers with more advanced critical thinking capabilities are more successful.

Teaching is a multidimensional process and it can affect learners in various ways; thus it is necessary to strengthen those pivotal attributes that leads to positive changes in learners. An extensive range of language education research was dedicated to the characteristic features of successful language teachers. Some of these studies have mentioned a broader conception of teacher success than one which only matches importance to professional qualities like language proficiency and managing skills. In an attempt to continue the line of developments in psychology and cognitive science, this increase in language education research has investigated the impact of language teachers' various cognitive, affective and personality characteristics on their teaching skills. Following this line of research, another essential domain in which to examine the concept of teacher success in foreign and second language teaching programs is L2 teachers' critical thinking ability. Teacher's ability to think critically is a viable component in assessment of teaching effectiveness in programs designed for teaching second language. As Wright (2000) states "I think critically; therefore I live better" (p. 11), thinking critically makes the way of life better. John Dewey in the early 1900s emphasized on rationale of reflective (critical) thinking that affected all subject area. He also discussed in one of his books named Democracy and Education, that the reflective thinking was very important for a democracy to survive.

Bloom's Taxonomy influences educators in their thinking and teaching. It is used by teachers to design their lessons and make up test questions. Bloom (1956) classified thinking skills into six categories: knowledge, comprehension, application, analysis, synthesis, and evaluation. In remembering of previously learned material the knowledge is applied. It is the lowest level of learning outcomes. Here, students search for objective answers for "Who", "What", "When", "Where", and "How". Learning knowledge comes before anything. It is the first step when someone looks critically into a piece of text. According to this model the person need not to have many pre-conceived notions about passage; he just read it so that perceives objective facts. It is useful to grasp the meaning of the materials. Before someone uses knowledge he/she need to comprehend. Comprehension includes classifying, estimating, explaining, illustrating, predicting and summarizing. By using comprehension you can communicate to others what you have learned. The higher level of understanding than comprehension is application. In this level there is a major struggle, because one thinks that "how do I apply this to what I am doing?" The one apply, change, interpret defend, and translate in application level. In analysis, knowing the content and structural form is important. The person needs exploring, contrasting, investigating, researching, referring, and examining. Here the individual searches more and tries to find conclusion. It means while reading a novel the person from an in-depth discussion about the book. He/she searches for evidence to find meaning. Analysis is applied to prove correction of something. It is also used to demonstrate relevancy, usefulness, and qualities of knowledge learned. The next is synthesis, that is putting parts together to form a new whole. It brings thinkers to the level of adapting, combining, developing, experimenting, imagining, predicting, and speculating. By synthesizing the individual can see the bigger picture of whatever she/he has learned. Creativity plays a big role in this stage. It provides a chance to suggest their own idea and new perspectives. Emphasis is not put enough on synthesis at school. It is educators' job to help learner not only obtain knowledge but also give them motivation think on their own. The last level is evaluation. It is the ability to judge the value of material. It is the highest in the cognitive hierarchy because it contains elements of knowledge, comprehension, application, analysis, and synthesis, ability to assess, command, conclude, critique, and support her/his finding (bloom, 1956).

During the past two decades language teachers are not to transfer knowledge to learners but are as transformative intellectuals. With regard to English teaching materials, Tomlinson (2012) believed that course books transfer and communicate target language and target culture and there is a risk as these course books are authority in the classroom and learners might blindly accept any view in the books. The use of critical thinking 
in teaching can overcome the problem. Shirkhani and Fahim (2011) stated that people with more critical thinking are more successful in monitoring their own book. But according to Kabilan (2000) unfortunately enhancing CT skills has been peripheral and not so important goal for language teaching methodologies. Thus, language teachers should pay attention to CT as an essential part in language learning (Lipman, 2003).

The significance of critical thinking in education is acknowledged by many educators. Elton (2006) believed that effective teaching is "a teaching that leads to effective learning" (p. 1). So teachers' understanding of an effective teacher has impact on learners' learning (Dembo\& Gibson, 1985; Goddard, Hoy, \& Hoy, 2000). There are investigations of successful language teachers and language teachers' education that improve such features. Schaferman (1991) believed that education must involve 'how to think' and 'what to think'. The ability to apply critical thinking can be central to teacher effectiveness, a quality that presupposes teachers' ability and willingness to think critically.

In recent years researchers have continued to pay attention to thinking skills that is of great significance (Paul, 1990, cited in Longman, Atkinson, \& Breeden, 1997). While designing course materials and improving educational levels, teachers thinking and their attitudes are of crucial factors. Although there are not many studies in these fields in Iran. Thus, teachers' mentality in the process of teaching is neglected to some extent. Considering this existing gap, the goal of this study was to go through the mind of teachers and to investigate how they think. Furthermore it aimed to find out the effects of critical thinking ability on teachers' success. This study has been done in different context and with different variables in comparison to previous studies.

\section{Literature review}

Teachers are an ultimate key, if not the key, to successful education and that they have a critical role in bringing about educational reform (Hargreaves \& Fullan, 1992; Suwandee, 1995). This is true about education and language education. Therefore, not a surprising that an extensive range of language education research was dedicated to the characteristic features of successful language teachers. Some of these studies have mentioned a broader conception of teacher success than one which only matches importance to professional qualities like language proficiency and managing skills. In an attempt to continue the line of developments in psychology and cognitive science, this increase in language education research has investigated the impact of language teachers' various cognitive, affective and personality characteristics on their teaching skills. Among those investigated areas, one can concern EFL teachers' multiple intelligences (Pishghadam \& Moafian, 2007), emotional intelligence (Hashemi, 2008), and self-efficacy (Moafian \& Ghanizadeh, 2009). Following this line of research, another essential domain in which to examine the concept of teacher success in foreign and second language teaching programs is L2 teachers' critical thinking ability. In a rapidly-changing world where almost nothing can be taken for granted, 'critical thinking' seems to be a solution. Regarding critical thinking as the ability to discipline and control thinking to process information more easily, effectively and efficiently (Paul, 1990; cited in Longman, Atkinson, \& Breeden, 1997), it is important for learners to perform well not only in educational systems, but also in future workplaces, and social areas. Critical thinking researches have focused on ways of developing this skill in learners (e.g., Dantas-Whitney, 2002; Faravani, 2006), and failed to examine its application to teachers' success and the effectiveness of teacher education programs. It is obvious that in order to train learners for ways of thinking, teachers themselves must be able to think in those terms. The questions of how teachable critical thinking is and to what extent current EFL/ESL teacher education programs implicitly or explicitly draw on the construct are yet to be answered. However, before addressing such questions, the number-one issue to be investigated is the extent to which EFL teachers with more advanced critical thinking capabilities are more successful.

\subsection{Successful teaching}

Examining the teacher success is pivotal. Educators can anticipate professional development directions and improve the quality of teacher education. Pettis (2000) stated that teachers are change agents. Sanders and Rivers 
(1996) found that teachers are the most essential factors affecting learner achievement. Similarly, King (2003) believes that teaching is a complex activity influenced by teacher quality and teacher quality is a predictor of learner performance. These studies demonstrate the significance of teachers' role in the process of learning. Some of these studies emphasize on teachers' thinking skills and cognitive, affective, and personality traits of them. Elizabeth, May, and Chee (2008) examined successful teacher qualities. They categorize three groups of features influencing teacher success: personal qualities (e.g. caring for students, enthusiasm, holding individual teaching belief), professional qualities (e.g. classroom management), and contextual features (e.g. personal context, context beyond school). This viewpoint is more promising because of inclusion of such facets of critical thinking as self-reflection and concerning teaching context. Elizabeth at al. (2008) reported their studies on teacher effectiveness asserting that effective teachers have strong cognitive skills. Elton (2006) described effective teaching as "a teaching that leads to effective learning" (p. 1).

The ability to enhance critical thinking is pivotal to teacher effectiveness in this definition. In the similar way, Korthagen (2004) has suggested a five layer onion model to reach the properties of a good teacher; the layers are: behavior, competencies (knowledge, skills, and attitude), beliefs, identity and mission. Unlike others, Korthagen focused on teacher effectiveness in terms of not only teachers' attributes, but also influence of the whole ambience in which they operate. The significance of critical thinking in education is acknowledged by many educators. Elton (2006) believed that effective teaching is "a teaching that leads to effective learning" (p. 1). So teachers' understanding of an effective teacher has impact on learners' learning (Dembo \& Gibson, 1985; Goddard, Hoy, \& Hoy, 2000). There are investigations of successful language teachers and language teachers' education that improve such features. Schaferman (1991) believed that education must involve 'how to think' and 'what to think'.

According to Schafersman (1991) education involve not only "what to think" but also "how to think". Atkinson (1997) states that critical thinking concept has applied in the field of language education from L1. Although, he is skeptical in using it on faith, and consider language educators should use it carefully and cautiously. While, Atkinson's argument Davidson (1998) reciprocated referring to what Siegel (1989) calls "self-reflective justifactory strategy" (p.121) that means that even one wants to make a case against critical thinking, one needs to presuppose its validity, i.e. to be a critical thinker. Considering the cultural load of critical thinking, Davidson cities Ennis (1996) the problem for educators is how and when critical thinking should be drown upon.

Teachers have an essential role in bringing better learning and achievement in their learners. The methods teachers use are affected by their perception of effective teaching. Many researches have been done in relation to teachers' development during the past 60 years and they have tried to find criteria to investigate successful teaching. Researchers have established some attributes which are enthusiasm (Murray, 1991). Successful teaching is a highly debatable topic. For instance, the growth in psychology and cognitive sciences has conducted the researchers to consider cognitive, affective and personality characteristics of teachers and the role of them in teaching success. One viable domain to examine the concept of successful teaching in foreign language teaching is teachers' critical thinking. Critical thinking is the ability to form and control information more efficiently (Paul, 1990, cited in Longman et al., 1997). It is the ability to recognize a problem as well as attitude that searches for proof of the evidential. It is gathering knowledge about the truth of this proof and the ability to use this knowledge (Daly, 1998; Simpson \& Countney, 2002). So, it is important for teachers to be critical thinkers to be able to tech it to their learners. The researchers have focused on ways of developing it in learners (e.g. Dantas-Whitney, 2002; Faravani, 2006) and in teachers' practice because it is an essential and useful skill. Teaching is a multidimensional process and it can affect learners in various ways; thus it is necessary to strengthen those pivotal attributes that leads to positive changes in learners.

In recent years researchers have continued to pay attention to thinking skills that is of great significance (Paul, 1990, cited in Longman et al., 1997). Peterson (1995) believed that "good teachers are good for different reasons... What makes one teacher good (a successful task master) may not be true of the next one (an inspirer) 
or still another ( a subject matter authority)" (pp. 6-7).

\subsection{Critical thinking}

Critical thinking is not a novel idea. Our early ancestors appreciated those who used their critical skills to locate food sources or produce a better stone ax. The people who first wrote about critical thinking were Greeks. More than two thousand years ago, Socrates questioned people and discovered that they could not always establish their claims. He believed that, “...seeking reasons, obtaining evidence, questioning assumptions, analyzing concepts, and figuring out the implications of what was believed and acted upon were necessary for justifying any claim or action" (Wright, 2000, p. 11). Other Greek scholars, especially Plato and Aristotle, followed on Socrates' ideas and established the basis for western philosophy. In the middle Ages, St. Thomas Aquinas found that all his ideas needed to be tested against counter arguments before they could be believed.

Critical thinking has been a debatable research field across different disciplines for a long time. It was introduced by Greek philosophers first and has been used since the Greek Empire era up to now, obtaining a significant, influential status during its broad travel all over history. Many historians point out the stems of critical thinking can be traced from Socrates' teaching practice and vision 2,500 years ago. He showed a probing method for questioning that people could not logically justify their assertive claims to knowledge. Socrates' view of critical thinking that was supported by Plato, was then applied by Descartes and was a theme in essays of Montesquieu and John Locke (Rfaner, 2006).

In the Renaissance, Francis Bacon laid the foundations of modern science emphasizing collecting evidence and avoidance of "idols" made out of bad thinking, including the inappropriate usage of words and the tendency to become trapped in conventional modes of thought. René Descartes, in his Rules for the Direction of the Mind (as cited in Wright, 2000, p. 11),f ocused on the importance of subjecting all beliefs to critical inquiry. His "method of doubt" is willing to remove all beliefs about which one cannot be certain. Because the senses are not always trustworthy, for Descartes even data derived through the senses must be abandoned." Wright (2002) established, "I think critically; therefore, I live better" (p. 11).

In many years ago Socrates found out people could not justify their speech when he questioned them by his questioning method. For Socrates "seeking reasons, obtaining evidence, questioning assumptions, analyzing concepts, and finding out the implications of what was believed and acted upon were necessary for justifying any claim or action" (Wright, 2000, p. 11).

Critical thinking is a process that the person improves the quality of his/her thinking. One of the scopes in CT research is related to language teaching. Campbell (2000) stated that "teaching is a complex interaction including subject matter, content, teacher characteristics, pedagogy, resources, and learning context" (p. 50). While CT has been necessary today, we need professional teachers who can fulfill students' needs because we live in a highly technical society which changes every second. We need teachers who follow new methods in teaching process and think critically. They can help students to learn easily by using effective methods of critical thinking and using them creatively in their teaching style.

According to Bloom (1956) critical thinking is the ability of gaining knowledge through examining of ideas concerning these six levels: knowledge, comprehension, application, analysis, synthesis, and evaluation. In the low level of thinking skills are knowledge and compression while the others are in the higher level of thinking Skills. Scriven and Paul (2003) stated that it is based on universal intellectual values includes: clarity, accuracy, precision, consistency, relevance, sound evidence, good reasons, depth, breathe, and fairness. Eniss (1991) emphasized on practicality of critical thinking. He defines it as "reasonable, reflective thinking that is focused on deciding what to believe or do" (p. 6). He focuses on decision making about belief and action, the process of reflection and rationality of reason. It helps individuals to decide what to believe and how to solve problems. According to Fisher (2001) critical thinking is "a kind of evaluated thinking which involves both criticism and creative thinking and which is particular concerned with the quality of reasoning and argument which is 

presented in support of a belief or a course of action" (p. 13). Paul and Elder (2005) say critical thinking is the art of thinking. They identify the essence of it in two ways: 1) Identify its strength and weakness, and 2) Change it in improved form.

Radhakrishnan (2009) found that a critical thinking teacher has some characteristics: he asks relevant question to check his students learning, he assesses arguments, he is attracted in finding new solutions, he can recognize criteria for analyzing ideas, he is able to give feedback because he listens carefully to his students, he can finds evidence to support beliefs, he examines problems, he refuses irrelevant and incorrect information. Ur (1996) said good teachers know their students and their learning styles, so they know how to challenge and make them interested in the subject. However it is difficult to reach all of the students in a personal level, quality teachers need to know their students level to help and mentor them and they want to have the students' attention and respect in order to teach them.

\section{Methodology}

In this study the goal was to measure the relationship between two variables i.e. teacher's critical thinking ability and successful teaching. The teachers were given WGCTA to fill out. Furthermore, their successful teaching was evaluated toward the end of the term as their students filled out the Successful Iranian EFL Teacher (SIET) questionnaire. Also, regression and correlational design were conducted.

\subsection{Participants}

To accomplish the purpose of the research, two groups randomly took part in this research. A sample of 50 male and female EFL teachers from different English language schools (Jahad-e- daneshgahi, Alefba, and Marefat). The second group of participants were the students of these teachers. They were 100 Iranian EFL learners who studied English in the above language schools and they were common among these teachers. The participants were selected randomly.

\subsection{Instrumentation}

The first instrument in this study was the Watson-Glaser critical Thinking Appraisal. It is comprised of 80 items. The first section of the questionnaire consists of 16 Likert scale items which are with the choices of 'true', probably true', insufficient data' 'probably false', and 'false'. The next 16 items were two scaled with alternatives ranging from made and not made and the other 33 items consisted the alternatives of follow and does not follow. Also the last 15 were followed by choices of strong and weak. Furthermore, to the face, content, construct, and criterion validity of the appraisal, its test-retest reliability has been demonstrated ( $\mathrm{r}=0.81)$ by Watson and Glaser (1980). The researcher used the Farsi version of the questionnaire that is translated by Faravani (2006) and its reliability is $85 \%$ (Cronbach's $\alpha=0.85$ ).

The second instrument was the Characteristics of Successful Iranian EFL Teachers Questionnaire (2009).It is designed by Moafian and Pishghadam consisting 47 Likert scale items that is followed by alternatives. Each item is followed by a 5-point Likert Scale, ranging from 'strongly agree' to 'strongly disagree'. The results of reliability analysis showed that the total reliability of the questionnaire is very high (Cronbach' alpha $=.94)$. The total reliability of these two questionnaires was estimated by Bagherkazemi and Birjandi (2010).

\subsection{Data collection}

The teachers were given WGCTA questionnaire and they were asked to think about them and then answer in their free time. The next step was giving the questionnaire of successful teaching to their own learners and they were asked to record their initial thoughts about their teachers. 


\subsection{Data analysis}

The data were analyzed through the SPSS. As two continuous variables were involved, the Pearson correlation coefficient for the two sets of scores was calculated. Multiple regression was conducted with the five aspects of critical thinking underlying Watson-Glaser CTA-Form as the set of dependent variables and the obtained SIET scores as the independent variable. In the next step the R value and ANOVA were conducted. Pearson correlation coefficient of the variables were not that much high, excluding the correlation between the age and experience.

\subsection{Procedure}

To obtain measures of teachers' critical thinking ability the teacher thinking questionnaires were administered to 50 teachers. The participants were given enough time to fill the questionnaire at their homes. It took two month. The next stage of the study involved administrating the Characteristics of Successful Iranian EFL Teachers Questionnaires which were filled by their students in the class time in twenty minutes. There were 100 students in this research. For this purpose, the correlations of the variables, ANOVA, coefficients, and regression were conducted.

\section{Result}

Success or failure of teachers in educational setting is always tied with their knowledge and their experience; many studies attempted to explore the most effect factors on teachers' performance (Hashemi, 2008; Moafian \& Ghanizadeh, 2009; Tamblyn, 2000). To reach a unanimous result the issue was analyzed from different perspective and different factors were investigated (i.e. experience, critical thinning ability, age, etc.). Accordingly the present study was an attempt to assess the relationship between different factors which leads to a successful teaching.

An in depth analysis of variables which was considered as the sources of variance including critical thinking ability, age, teaching experience, successful teaching ability is provided in the following.

\section{Table 1}

Descriptive statistics of CT, age, experience, successful teaching

\begin{tabular}{|c|c|c|c|c|}
\hline & $N$ & Minimum & Maximum & Mean \\
\hline Critical thinking ability & 50 & 16.00 & 59.00 & 46.56 \\
\hline Age & 50 & 23.00 & 42.00 & 29.00 \\
\hline Teaching experience & 50 & 1.00 & 15.00 & 5.78 \\
\hline Successful teaching ability & 50 & 47.00 & 182.00 & 80.02 \\
\hline
\end{tabular}

Table 1 shows the required information about the participants of the present study. The 50 participants with the average age of 29 years old were examined in terms of both critical thinking ability and successful teaching. The CTA ranges from 16 to 59 for the participants. All the participants had at least 1 year of experience of teaching. The factor of age ranges from 23 to 42 for all the participants. And the most level of successful teaching investigated by the researcher was equal to 182 . Besides, it is safe to say that participants had at least one year and at most 15 years of teaching experience.

As the table 2 correctly represents the between Pearson correlation coefficient the variables are not that much high, excluding the correlation between the age and experience, which could be a good indicator of importance of experience. The correlation between the age and experience is .92 ( $p<.05$, Sig. 2 tailed) and presents a high level of correlation between two variables and an increase in one provides an increase in the other variable. As the age of teachers increases their experience increases and for the beginner teachers, it is safe to say that, a low level of experience is considered. 
Relationship between novice and experienced EFL teachers' critical thinking ability and their successful teaching

Table 2

Correlations of CT, age, experience, successful teaching, gender

\begin{tabular}{lccccc}
\hline & CTA & Age & Experience & Successful teaching & Gender \\
\hline CTA & 1 & & & & \\
Age & $.647 *$ & 1 & & & \\
Experience & .179 & $.920 *$ & 1 & & \\
Successful teaching & .120 & .025 & .130 & 1 & 1 \\
Gender & .352 & .291 & .013 & .487 & \\
\hline Note. ${ }^{*}$ The correlation is significant at the level of .05 & & &
\end{tabular}

Note. ${ }^{*}$ The correlation is significant at the level of .05

On the other hand the same pattern holds for the correlation between the age and critical thinking ability. The correlation coefficient equals to .647 exists between the age and CTA implies that the more the age increases the higher level of CAT could be achieved by teachers $(p<.05$, Sig. 2 tailed).

Based on the obtained results, the correlations between CTA and experience, gender, and successful teaching were $.179,-134, .120$ respectively, showing that there is no significant correlation between CTA and any of these factors at the level of $p<.05$. The variable namely age is considered as an important and effective factor in the present study. It had two significant correlations with CTA and experience and also positive correlation with successful teaching. Experience and successful teaching did not achieve a high level and also significant correlations with the variables included in the study and the only consequences of their presence were the positive contribution in analysis.

It is notable that the factor gender, except in one case, did not show an effective role in having correlations with other variables. The biggest amount of correlation was between the gender and successful teaching equal to .487 . By collecting the proper data concerning the relationship between successful teaching, gender, age, experience and CTA a multiple regression analysis was conducted.

Table 3

Model Summary; $R$ square of dependent and independent variables

\begin{tabular}{ccccc}
\hline Model & \multirow{2}{*}{$\mathrm{R}$} & \multirow{2}{*}{ R Square } & Adjusted R square & $\begin{array}{c}\text { SD Error of the } \\
\text { estimate }\end{array}$ \\
\hline 1 & .358 & .128 & .050 & 8.53188 \\
\hline
\end{tabular}

Table 3 serves to show the results of analyses by the proposed model. The box heading R Square shows that .128 of CTA (as the dependent variable) is predicted by independent variables in the model. In other words $12.8 \%$ of the CTA could be predicted by successful teaching, gender, age, and experience; this fact shows that there is not a high level of relationship between the variables included in the study and just a limited amount of variation could be accounted by independent variables. These results confirm the respective low amount of correlation in the table 4.2. A confirmation of this claim regarding the weak relationship between the variables is seen in the table 4 (ANOVA) where level of significance is .178 (this is not significant in $p<.05$ ).

\section{Table 4}

ANOVA; regression and residual between dependent and independent variables

\begin{tabular}{llllll}
\hline Model & Sum of Squares & Df & Mean Square & F & Sig. \\
\hline Regression & 480.634 & 4 & 120.159 & 1.651 & .178 \\
Residual & 3275.686 & 45 & 72.793 & & \\
Total & 3756.320 & 49 & & & \\
\hline
\end{tabular}

By taking into account the aforementioned results of ANOVA we can say that there is no significant relationship between the dependent variable and independent variables of the study $(\mathrm{Sig}=.178)$; in the case that the amount of Sig was less than .05 a significant difference was probable between the variables. The mean score for the regression model was equal to 120.159 while the mean score for the residuals was equal to 72.793 . 
Due to the results represented in table 5 (Coefficients of partial correlations) the analytical investigation of the correlations could be investigated.

Table 5

Coefficients of age, experience, successful teaching, gender

\begin{tabular}{|c|c|c|c|c|c|c|c|c|}
\hline \multirow[t]{2}{*}{ Model } & \multicolumn{2}{|c|}{$\begin{array}{c}\text { Unstandardized } \\
\text { coefficients }\end{array}$} & \multirow{2}{*}{$\begin{array}{c}\begin{array}{c}\text { Standardized } \\
\text { coefficients }\end{array} \\
\text { Beta }\end{array}$} & \multirow[t]{2}{*}{$\mathrm{t}$} & \multirow[t]{2}{*}{ Significant } & \multicolumn{3}{|c|}{ Correlations } \\
\hline & $\mathrm{B}$ & SE & & & & Zero-order & $p r$ & Part \\
\hline CTA & 17.992 & 16.172 & & 1.113 & .272 & & & \\
\hline Age & 1.285 & .687 & .690 & 1.870 & .068 & .247 & .269 & .260 \\
\hline Experience & -1.136 & .888 & -.475 & -1.279 & .208 & .179 & -.187 & -.178 \\
\hline Gender & -3.121 & 2.569 & -.171 & -1.215 & .231 & -.134 & -.178 & -.169 \\
\hline $\begin{array}{l}\text { Successful } \\
\text { teaching }\end{array}$ & .038 & .034 & .165 & 1.137 & .262 & .120 & .167 & .158 \\
\hline
\end{tabular}

As indicated in the table 5 (Coefficients) no one of the variables shows a significant correlation at .05 level of significance with CTA. In order to find the strongest unique contribution of each independent variable in the model the standardized coefficients under the box headed Beta was checked; age had the strongest unique but not statistically significant $(\mathrm{Sig}=.272, p<.05)$ contribution to the model (Beta=.690). Likewise, the variable named experience had followed the age with respect to its contribution to the model but same as the age it was not a significant correlation between the variables $(\mathrm{Sig}=-1.279, p<.05)$. A detailed analysis of correlation was achieved by considering the correlation column into account, the section headed the Part correlations provides the information about how much of the dependent variable (CTA) is explained by the other independent variables namely age, experience, gender, successful teaching. In this case age, experience, gender, successful teaching respectively had $7,3,2.8$, and 2.5 percent of unique contribution to the explanation of CTA. In fact the largest amount of part correlation belonged to the age (alpha $=.26$ ) followed by experience (alpha $=-.178)$. It is necessary to say that no multicoliniarity was not a concern among the variables of the study the tolerance levels are not below .1 and the VIF scores are well beneath 10 .

This chapter has presented the results of this study by answering the research questions and summarizing the results in tables and figures. It shows that there is no significant relationship between CTA and successful teaching. Furthermore, it reveals that gender, age, and experience have no significant relationship with teacher's critical thinking ability.

\section{Conclusion, discussion, and implication of the study}

In recent years, teacher education programs have become more concerned with enhancing successful teaching attributes. Educators believe that there is the need to integrate critical thinking skills into educational systems in the changing world. The present study intended to explore if there was any significant relationship between Iranian EFL teachers' critical thinking ability and their successful teaching. The results revealed that teachers were not totally familiar with critical thinking skills. Lack of attention to critical thinking skills in Iranian teachers may be regarded as an important factor in unawareness of them. According to Hashemi et al. (2010) Iranian education system emphasizes on knowledge transmission and the main problem in this system is the goal-centered being instead of being process-centered.

The results revealed that there is no significant relationship between variables. The correlation indicates that generally high levels of successful teaching as evaluated by EFL learners are not related to high levels of critical thinking of teachers. The current study revealed that those teachers who are successful in their teaching are not necessarily critical thinkers in their teaching profession.

Although a component such as age can predict critical thinking ability of teachers and higher levels of it enhances their thinking ability. In other words, teachers' thinking of their teaching practices tends to increase over time and with every year of teaching; hence it guarantees their teaching success. The theory developed by 
Patricia Gurin and her colleagues revealed that why we should expect that age and experiences would influence aspects of self (Gurin et al., 2002; also see Gurin, 1999). Building on theories and evidence from psychology, these scholars suggest that through experiences individuals learn about perspectives and ways of living different than their own or those they have previously encountered. So, it affects their thinking and fosters knowledge gain. Without experiences and increasing age, persons run the risk of making commitments to ideas, or careers without exploring options - having very few options to choose. On the other hand, experienced teachers use CT skills more frequently than novices which is indicative of the difference between them and more familiarity of experiences with the skills.

There is another conclusion that we can draw upon: results support the idea that males and females were not different in critical thinking ability. Actually gender does not have any strong effect in the promotion of critical thinking skills of teachers. Howe (2000) asserted that there were meaningful differences in teachers' conceptions of critical thinking and teachers' cultural background accounted for more differences in their conceptions rather than factors such as gender or subject area.

The results indicated that that a majority of the teachers believed that they were doing their jobs properly. They seemed unwilling about using deep thinking to improve their performance. They knew the importance of critical thinking but at the same time felt there is no need to use it since they could teach successfully without that. It supports the finding that these teachers did not value this ability. They did not link between what they did in the classroom and how it could influence student performance. The learners could clearly identify twelve dimensions of successful teachers, namely: teaching accountability, interpersonal relationship, attention to all, examination, commitment, learning boosters, creating sense of competence, teaching boosters, physical and emotional acceptance, empathy, class attendance, dynamism. The study firmly supports the conclusion that effective teachers are more interested in subject which they are teaching than less effective teachers. They respect learners' ideas and have a good relationship with them. They provide an interesting atmosphere in class to attract learners' attention such as using pictures. As a matter of fact they are knowledgeable enough and their knowledge is up to date. They know the strategies of teaching English and are aware of class management techniques. They have self-confidence and are very energetic in the class. These are some of important qualities of teachers which influence their teaching success. Swandi (1995) also believes that learners are the best source to predict teacher quality.

Research and practice in teacher education are needed to encourage teachers to support high-CT in their profession. Similar conclusions were drawn by Pogrow (1990a, 1996b), Raudenbush et al. (1993), and Zohar et al. (2001). However there is little theory or researches specifically devoted to fostering change in teachers' beliefs and CT ability, some techniques that could be extended on teacher change include encouraging teachers to reflect on their CT-related beliefs in discussions and learner's behaviors (Feinman- Namser et al., 1989; Hollingsworth, 1989; Holt-Reynolds, 1992; Placier \& Hamiliton, 1994; Richardson \& Hamilton, 1994; Stallings, 1989) and assigning novice teachers to observe the differences between the instructional approaches used by experienced ones to teach different learners (Feinmen-Nemser et al., 1989; Placier \& Hamilton, 1994; Pogrow \& Brink, 1993). Also, asking teachers to analyze high-CT and low-CT instructional planning to see the impacts of it on effective teaching (Anderson et al., 1995; Barnett \& Sather, 1992; Blumenfeld, Hicks, \& Krajcik, 1996; MorineDershimer, 1993; Richardson \& Hamilton, 1994).

Wenglisky (2000) asserted that teacher's competency is the key factor in learners' success. To obtain that, improving teaching abilities is responsibility of teachers (Krendle, 1996) and one way to reach the aim is enhancing thinking ability in the teachers. They need to analyze the arguments, make inferences using inductive or deductive reasoning, evaluate, make decision, ask and answer questions for clarification, and interpret and explain (Ennis, 1985; Paul, 1992; Facione, 1990; Halpern, 1998; Case, 2005; Lipman, 1988; Willingham, 2007). Richards (1992) states that effective teaching is the relationship among teachers, curriculum, learners, and subject matter. However, many teachers indicated that some people may never become critical thinkers due to their personality. These teachers did not value this skill in their life. In general they agreed that critical thinking 
Beizaee, A., \& Akbari, O.

need not to be incorporated into instruction.

Acknowledgement: My deepest gratitude is extended to my dear professor Dr. Akbari who inspired me a lot and gave me an identity in this field. His guidance and insightful recommendations helped me through the process of writing this article. I cannot write how much gratitude I feel towards him for his careful advices and suggestions. I also wish to thank my family members for support and encouragement throughout my life. I extend my thanks to my instructors especially Dr. Zareian in the department of English language teaching in Islamic Azad university of Neishabour.

\section{References}

AfshariSaleh, R. (2010). An observational and attitudinal study of effective teaching: A case of EFL expert and novice teachers. Unpublished Masteral thesis, Ferdowsi University, Mashhad, Iran.

Akkaya, N. (2012). The relationship between teacher's candidate's critical thinking skills and their use of reading strategies. Social and Behavioral Sciences, 47, 797-801.

Al-Issa,A., \& Al-Bulushi, A. (2012). English language teaching reform in Sultanate of Oman: The case of theory and practice disparity. Education Research Policy and Practice, 11, 141-176. http://dx.doi.org/10.1007/s10671-011-9110-0

Alwadai, M. A. (2014). Islamic teachers' perceptions of improving critical thinking skills in Saudi Arabian elementary schools. Journal of Education and Learning, 3(4), 37-48. http://dx.doi.org/10.5539/jel.v3n4p37

Atay, D. (2008). Teacher research for professional development. ELT Journal, 62(2), 139-148. http://dx.doi.org/10.1093/elt/ccl053

Birjandi, P., \& Bagherkazemi, M. (2010). The relationship between Iranian EFL teachers' critical thinking ability and their professional success. English Language Teaching, 3(2), 135-145. http://dx.doi.org/10.5539/elt.v3n2p135

Boloori, L., \& Naghipoor, M. (2013). The relationship between critical thinking and performance of Iranian EFL learners on translation tests. International Journal of Applied Linguistic Studies, 1(1), 7-13.

Choy, S., \& Oo, P. (2012). Reflective thinking and teaching practices: A precursor for incorporating critical thinking into the classroom. International Journal of Instruction, 5, 11-24.

Duron, R., Limbach, B., \& Waugh, W. (2006). Critical thinking framework for any discipline. International Journal of Teaching and Learning in Higher Education, 17(2), 160-166.

Dwyer, C. P., Hogan, M. J., \& Stewart, I. (2012). An evaluation of argument mapping as a method of enhancing critical thinking performance in e-learning environments. Metacognition Learning, 7, 219-244. http://dx.doi.org/10.1007/s11409-012-9092-1

Elsegood, S. (2007). Teaching critical thinking in an English for academic purposes program using a 'Claims and Supports' approach. Indonesia Australia Language Foundations, Bali, Indonesia.

Ezzatian, S. (2013). The differential effects of debate and media analysis as relate to enhancing EFL learners' critical thinking ability and writing performances. Unpublished Masteral thesis, SheikhBahaee University, Iran.

Fahim, M., \& Askari, H. (2013). Does teaching critical thinking affect students' L2 attitudes? Journal of Language and Translation, 3(6),17-26.

Farahani, D., \& Mirsharifi, F. (2007).Effective and less effective teacher questioning and corrective feedback behavior in an EFL context. Pazhuhesh-e Zabanha-ye Khareji, 41, 5-23.

Ghadiri, M., Tavakoli, M., \& Ketabi, S. (2014). Development of a criticality-oriented English teaching perceptions inventory (CETPI) and exploring its internal consistency and underlying factor structure. Current Psychology, 34(2), 268-281. http://dx.doi.org/10.1007/s12144-014-9256-Z

Ghaemi, H., \& Taherian, R. (2011). The role of critical thinking in EFL teachers' teaching success. MJAL, 3(1), $8-22$ 
Relationship between novice and experienced EFL teachers' critical thinking ability and their successful teaching

Grosse, M. M., \& Lombard, B. J. J. (2007). The relationship between culture and the development of critical thinking abilities of prospective teachers. Teaching and Teacher Education, 24, 1364-1375. http://dx.doi.org/10.1016/j.tate.2007.10.001

Hashemi, M. (2008). On the role of teachers' emotional intelligence on their pedagogical success. Unpublished Masteral thesis, AllameTabataba'i University, Tehran, Iran.

Innabi, H., \& Sheikh, O. E. (2006). The change in mathematics teachers' perceptions of critical thinking after 15 years of educational reform in Jordan. Educational Studies in Mathematics, 64, 45-68. http://dx.doi.org/10.1007/s10649-005-9017-x

Karami, M., Rajaei, M., \& Naamkhaah, M. (2014). Investigation of tendency toward critical thinking in secondary school teachers and its role on their teaching style. Research in Curriculum Planning, 11(13), 34-47.

Klassen, R., \& Tze, V. (2014). Teachers' self-efficacy, personality, and teaching effectiveness: A meta-analysis. Educational Research Review, 12, 59-76. http://dx.doi.org/10.1016/j.edurev.2014.06.001

Lai, E. R. (2011). Critical thinking: A literature review. Retrieved from http://www.pearsonassessments.com/research

Markley, T. (2008). Defining the effective teacher: Current arguments in education. Unpublished Masteral thesis, White Mountains Regional School District, New Hampshire.

Marrapodi, J. (2003). Critical thinking and creativity: An overview and comparison of the theories. A paper presented in partial fulfillment of the requirements of ED7590 critical thinking and adult education, Providence, RI.

Masduqi, H. (2011). Critical thinking skills and meaning in English language teaching. TEFLIN Journal, 22(2), 185-199.

McGee, M. (2001). Measuring effective teaching in inclusive classroom. Unpublished Masteral thesis, University of Toronto, Canada.

Mirmohammadi Meybodi, S. J., MazloomiMahmoodabadi, S.S., Sharifpour, Z., Shahbazi, H., \& Mohamadloo, A. (2013). The characteristics of effective teaching based on viewpoints of ShahidSadooqi university of Medical Sciences. Medical Education Development, 5(9), 52-63.

Moafian, F., \& Ghanizadeh, A. (2009). The relationship between Iranian EFL teachers' emotional intelligence and their self-efficacy in Language Institutes, System, 37(4), 708-718. http://dx.doi.org/10.1016/j.system.2009.09.014

Moafian, F., \& Pishghadam, R. (2009). Construct validation of a questionnaire on characteristics of Successful Iranian EFL teachers. Pazhuhesh-e Zabanha-ye Khareji, 54, 127-142.

Moaven, B. (2008). The relationship between learners' critical thinking ability and their performance in the reading sections of the TOFEL and IELTS tests. Unpublished Masteral thesis, Ferdowsi University, Mashhad, Iran.

Moradan, A., \& Pourasadollah, R. (2014). Teachers' thinking about their teaching: A critical study on Iranian TEFL teachers. Social and Behavioral Sciences, 98, 1194-1203. http://dx.doi.org/10.1016/j.sbspro.2014.03.534

Noormohammadi,S. (2012). Teacher reflection and its relation to teacher efficacy, personality, and autonomy. Unpublished Doctoral dissertation, Tarbiat Modares University, Tehran, Iran.

Paul, R., \& Elder, L. (2002). Critical thinking concepts and tools. Retrieved from http://www.criticalthinking.org Sadeghdaghighi, A. (2011). Developing a performance-based assessment of students' critical thinking skills. Unpublished Masteral thesis, Ilam university, Iran.

Shangarffam, N., \& Rahnama Roud Poshti, N. (2011). The relationship among EFL teachers' critical thinking, self-efficacy, and their perception of effective teaching. The Journal of Applied Linguistics, 4(1), 178-207.

Silcock, P. (1993). Can we teach effective teaching? Faculty of Education, 45(1), 13-19. http://dx.doi.org/10.1080/0013191930450102

Stapleton, P. (2010). A survey of attitudes towards critical thinking among Hong Kong secondary school teachers: Implications for policy change. Thinking Skills and Creativity, 6, 14-23. 
Beizaee, A., \& Akbari, O.

http://dx.doi.org/10.1016/j.tsc.2010.11.002

Tamblyn, P. (2000). Qualities of success: Lessons from a teacher career. Education Canada, 40(1), 16-19.

Tebbs, T. (2000). Assessment teacher's self-efficacy toward teaching thinking skills. Unpublished Masteral thesis, Universiy of Connecticut, Connecticut.

Thadphoothon, J. (2005). Promoting critical thinking in language learning through computer-mediated collaborative learning: A preliminary investigation. Unpublished Doctoral dissertation, University of Canberra of Australia, Australia.

Williams, R. L. (2005). Targeting critical thinking within teacher education: The potential impact on society. The Teacher Educator Journal, 40(3), 163-187. http://dx.doi.org/10.1080/08878730509555359

$\mathrm{Xu}, \mathrm{J}$. (2011). The application of critical thinking in teaching English reading. Theory and Practice in Language Studies, 1(2), 136-141. http://dx.doi.org/10.4304/tpls.1.2.136-141 